\title{
The link between black fungus and Covid-19 disease in diabetes mellitus patients
}

\author{
Abdulmutalib Alabeed Allaq ${ }^{1}{ }^{\text {* }}$, Hana Moftah Ebrahem Kamoka ${ }^{2}$, Norrizah Jaafar Sidik ${ }^{1}$, Aziyah Abdul-Aziz ${ }^{1}$, \\ Alaa Imad Abdulrazzaq ${ }^{1}$, Hasan Mohammed Agha ${ }^{1}$, Muhanad Abdullah Abdulsamad ${ }^{3}$, Esam Bashir Yahya ${ }^{4}$, \\ Asita Elengoe ${ }^{2}$
}

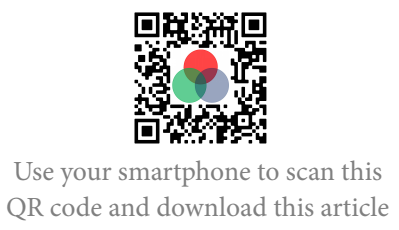

${ }^{1}$ Faculty of Applied Sciences, Universiti Teknologi MARA, 40450 Shah Alam, Selangor Darul Ehsan, Malaysia

${ }^{2}$ Department of Biotechnology, Faculty of Science, Lincoln University College, 47301 Petaling Jaya, Selangor, Malaysia

${ }^{3}$ Department of Zoology, Faculty of Science, Sabratha University, 00218 Sabratha, Libya

${ }^{4}$ School of Industrial Technology, Universiti Sains Malaysia, 11800

Penang, Malaysia

\section{Correspondence}

Abdulmutalib Alabeed Allaq, Faculty of Applied Sciences, Universiti Teknologi MARA, 40450 Shah Alam, Selangor Darul Ehsan, Malaysia

Email: alabeed119@gmail.com

History

- Received: Sep 18, 2021

- Accepted: Nov 16, 2021

- Published: Nov 29, 2021

DOI : 10.15419/bmrat.v8i11.705

\section{Check for updates}

\section{Copyright}

(c) Biomedpress. This is an openaccess article distributed under the terms of the Creative Commons Attribution 4.0 International license.

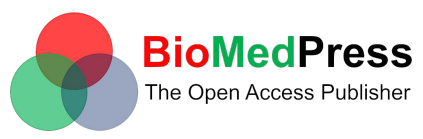

\begin{abstract}
Introduction: The emergence of the novel coronavirus disease (COVID-19) pandemic has conditioned the whole world to search for an ultimate cure for the infection. Therefore, all countries with no exception have embraced vaccines in addition to other pharmacological drugs. The consequences of the pandemic include material and human losses in all countries. Another emerging disease is a black fungus. The black fungus is a pathological phenomenon that arises as a result of exposure to mucormycosis. It is observed concurrently with recovery from the virus. The infection has symptoms and risks that do not reduce the risk of infection by COVID-19. Methods: Information was gathered from the review of the relevant literature obtained from various databases, such as Science Direct, Springer, PubMed, Google, and Google Scholar. Results: The relationship between diabetes, COVID-19, and mucous fungus is such that diabetes weakens the immune system which helps the COVID-19 virus. Conclusion: The decline of the immune system facilitates secondary infections such as the mucous fungus, especially in the recovery phase from the virus. Therefore, in this review, information about the new pandemic and its risks have been summarized. Key words: black fungus (mucormycosis), COVID-19, diabetes
\end{abstract}

\section{INTRODUCTION}

The world is yet to recover from the latest novel coronavirus disease (COVID-19) ${ }^{1-3}$. Many countries around the world are still struggling in the fight against the pandemic. One of the countries that is undergoing an unfavorable rise in the number of cases of COVID-19 in its second wave is Egypt with a total of 295,585 cases and 16,836 deaths as of $10^{\text {th }}$ September 2021. This is according to the Worldeometer, which says that it is rising with every passing day ${ }^{3-5}$. The recent surge in COVID-19 cases has a correlation with several of the attributes with the new highly infectious variants. This includes the violations of the standard protocols in the field of public health such as hand washing, using a mask, and the maintenance of social events. This is as well as organising large events such as the Kumbh Mela (Indian major pilgrim) and rallies attracting enormous crowds ${ }^{3-8}$.

The aftermath of COVID-19 is the emergence of another disease. The black fungus (mucormycosis) is a fungus whose infection is rare. It occurs due to infection by the fungal mucus found in soil, compost, plants, and fruits. This is in addition to the presence in the nasal mucus of healthy people ${ }^{9}$.
It has been noted that the recent occurrences of the COVID-19 effects have been connected to fungal infection symptoms such as mucormycosis and aspergillosis. Significantly, critically ill patients on steroid therapy were affected mainly by invasive mucormycosis post-COVID-19, which is a consequence of the current jump in COVID-19. During the pandemic's second wave in India, the black fungus is described in relation to COVID-19 by many case reports and case series ${ }^{10,11}$

The disease has a range of symptoms. Convectional breathing problems can often lead to severe cases that can aggravate secondary infections by opportunistic microorganisms such as molds and yeast infections. This is when the services of oxygenation and mechanical ventilation become necessary ${ }^{12,13}$. COVID19 patients co-infected with fungus in intensive care units (ICUs) have been examined in the course of the present severe acute respiratory syndromecoronavirus-2 (SARS-CoV-2) pandemic ${ }^{14-17}$.

The random and extended administration of steroids by clinicians in patients with mild COVID-19 is a substantial contributor to the development of mucosal mycosis in people with diabetes. This can cause pancreatic islet cell damage. Sugar levels may also arise as 
a result of the inflammatory response, which causes an increase in insulin ${ }^{\mathbf{1 0 , 1 8}}$.

In India, black fungus cases have been observed in COVID-19 individuals treated and recovered. The most often reported infection site was rhinoorbital/rhino-cerebral mucormycosis ${ }^{10}$. These people had diabetes and were using corticosteroids to deal with the severity of COVID-19. This led to a higher death rate and exacerbated the pandemic scenario. The Severian triad is a group of three people that are related to each other ${ }^{19}$.

Infection with black fungus is widespread throughout the world, although it is rare. Between 1992 1993, the number of infected people in the San Francisco Bay Area was estimated to be approximately 1.7 cases per million people ${ }^{20}$. India is one of the countries with the largest spread of the disease. This is due to the high number of people with diabetes who are thought to be the most vulnerable to the disease ${ }^{21-23}$. The widespread of black fungus may also be due to the high humidity, which increases the spread of fungi ${ }^{\mathbf{2 4}}$. The relationship between diabetes, COVID-19, and mucous fungus is such that diabetes weakens the immune system which helps the COVID-19 virus. The decline of the immune system facilitates secondary infections such as the mucous fungus, especially in the recovery phase from the virus ${ }^{25,26}$.

Diabetic patients whose blood sugar is poorly managed amount to most cases in the two weeks after their recovery from COVID-19. The skyrocketing infection rate with black fungus has been influenced by the misuse of steroids. Other sources have reported that the Covid-19 virus has the ability to suppress the host's immune system, and that this has aided the propagation of the fungus. Some have used traditional herbs, stretching the health system to breaking point, while vaccines are in low supply ${ }^{3,6,8,27-29}$.

\section{PATHOGENESIS OF A BLACK FUNGUS}

Black fungus, often known as the mucormycosis infection, causes black colonies in the affected tissues. It generally starts in the nose and paranasal sinuses and progresses rapidly. It takes advantage of immune deficiency in humans to survive $\mathbf{6}^{\mathbf{6 , 8 3 0}}$. This fungus infiltrates the arteries. It develops thrombi within the blood vessels, reducing the blood flow, and causing necrosis of both hard and soft tissues ${ }^{8,31}$. In addition, the fungus can spread to the orbital and cerebral tissues if it enters the arteries ${ }^{\mathbf{3 0}}$. Mucormycosis usually appears as an acute infection with symptoms that include rhinocerebral, pulmonary, gastrointestinal, cutaneous ${ }^{32}$, and diffuse mucormycosis ${ }^{31}$. The infection might take a long time to develop and be relatively indolent, and it may finally lead to maxillary necrosis 6,8 .

Black fungus is more common in people with uncontrolled diabetes because their innate immunity makes it difficult for the polymorphonuclear phagocytes to remove the fungi. The sinuses are the most affected location in diabetic patients, followed by the pulmonary $\operatorname{areas}^{4,8,32,33}$

\section{THE ROLE OF DIABETES}

In India ${ }^{34}$, Iran ${ }^{35}$, the Middle East and North Africa $^{16}$, and Mexico ${ }^{35}$, the high prevalence of diabetes is thought to be responsible for the increasing cases of black fungus ${ }^{5,7,8}$. Diabetes mellitus is a chronic, life-threatening metabolic disorder and it is considered to be one of Egypt's leading causes of death $^{5,34}$

According to the International Diabetes Federation (IDF), Egypt is among the top ten nations globally in terms of diabetes patients. It is expected that the number of diabetic patients in the Middle East and North Africa (MENA) region is predicted to increase by $96 \%$, from 34.6 million to 67.9 million from 2013 to $2035^{36,37}$. In Egypt, diabetes affects $15.56 \%$ of individuals aged 20 to 79 years old, resulting in an annual mortality toll of 86,478 people with type- 2 diabetes accounting for more than $90 \%$ of cases of type 2 diabetes (T2DM) ${ }^{34}$. Generally, T2DM is caused when the pancreatic cells fail to secrete insulin and when the insulin-sensitive tissues fail to respond correctly to said insulin. T2DM may increase the chance of black fungus infection in post-COVID-19 patients. The patients with diabetes were identified as making up more than $80 \%$ of the black fungus cases. In addition, people with diabetes show less of an immunological response, which hypoglycemia medications exacerbate. Patients with a history of diabetes mellitus should be managed with extreme caution when treating COVID-19 ${ }^{5-7}$.

\section{CASE REPORT}

The increasing cases of COVID-19 are thought to be responsible for the increasing cases of black fungus infection. Recently, a case of an 84-year-old patient with black fungus who was infected with the dreaded COVID-19 virus was reported in Egypt. His symptoms included severe knee pains and the inability to stand on his feet easily. However, the viral infection was easily treated without the patient experiencing kidney and lung failure. This led to being depressed 
and unconscious. In addition, the black fungus affected his right eye, and the patient described his experience as one of the most difficult diseases that afflict humans.

\section{METHODS}

The information was gathered from the review of the relevant literature obtained from various databases, such as Science Direct, Springer, PubMed, Google, and Google Scholar.

\section{COVID-19 AND BLACK FUNGUS}

The severe acute respiratory syndrome resulting from coronavirus 2 (SARS-CoV-2) disease in 2019 (COVID-19) has been connected to several opportunistic bacterial and fungal diseases. Furthermore, the predominant fungal pathogens causing coinfection in COVID-19 patients include Aspergillosis and Candida. Several incidences of mucormycosis in COVID-19 patients have recently been documented globally. Most cases so far have been reported in India ${ }^{38,39}$. The environment includes an insufficient amount of oxygen (hypoxia), an increase in glucose (diabetes, new-onset hyperglycemia, and steroid-induced hyperglycemia), an acidic medium (metabolic acidosis, diabetic ketoacidosis (DKA)), and an increased level of iron (high ferritins). Low white blood cells phagocytic activity (WBC) seems to help germinate the Mucorales spores in people infected with COVID-19 ${ }^{40}$.

According to the literature, people who contract coronavirus and undergo treatment are in danger of acquiring immunodeficiency ${ }^{41}$. The COVID-19 treatment drugs work to attack the virus while also having a significant impact on the immunity. Because of the increase in the proportion of cytokines secreted by the immune system to resist the coronavirus, which weakens the body's defenses, physicians are forced to give the patient steroids to suppress the immune system and reduce the secretion of cytokines. Still, both cytokines and steroids cause high sugar levels and a weak immune system ${ }^{42}$.

\section{COMMON SYMPTOMS OF THE BLACK FUNGUS INFECTION}

Black fungus infection is mostly a respiratory or skin infection. The symptoms of infection include symptoms of the respiratory tract and sinus irritation ${ }^{28}$. Other symptoms and signs of black fungus infection include a cough, fever, headache, nasal congestion, and sinus discomfort ${ }^{27}$. Swelling on one side of the face, headaches, fever, nasal or sinus congestion, and black lesions on the nose or upper portion of the mouth have also been reported as signs of black fungus infection ${ }^{30}$. Other signs and symptoms of pulmonary (lung) mucosa disease include fever, cough, chest discomfort, and shortness of breath ${ }^{\mathbf{9 , 4 3}}$.

The signs and symptoms of skin infection include blisters or ulcers. The afflicted region may turn black. There may also be discomfort, excessive redness in the afflicted areas, and swelling surrounding the infected wound ${ }^{44}$.

Similarly, some of the intestinal mucosal disease symptoms include intestinal pain, nausea, and gastrointestinal bleeding. The early detection of the condition frequently leads to better treatment results $27,28,30,45,46$.

\section{TREATMENT}

Anti-fungal medication is considered to be the most appropriate and effective method of treatment. The treatment plan, however, is very costly because the treatment period may be extended up to 8 months. Among the most popular compounds used is Amphotericin $\mathrm{B}$, and the treatment period ranges from 5 days to 12 weeks until the patient reaches the point of recovery. In some severe cases, the treatment plan requires the removal of the parts that have been damaged to prevent the fungus spread and to maintain the patient's health ${ }^{47}$. Isavuconazole has recently been used as a treatment with FDA approval. In addition, studies have proven the ability of hyperbaric oxygen to treat black fungus since high-pressure oxygen can raise the efficiency of the neutrophils in terms of eliminating the fungi ${ }^{48}$.

According to the US National Library of Medicine, all dead and contaminated tissue must be removed quickly. The palate, sections of the nose, or eye elements may be removed during surgery, resulting in deformity. However, if this procedure is not performed, the odds of survival are significantly reduced. Antifungal medicine is also administered intravenously, commonly in the form of amphotericin B. Once the infection has been managed, the patient may be shifted to a different treatment, such as posaconazole or isavuconazole. When a person has diabetes, their diabetes levels must stay within a healthy range 49 .

Amphotericin B, Potassium iodide, miconazole, terbinafine, cotrimoxazole, hyperbaric oxygen, itraconazole, ketoconazole, and surgical debridement have been practiced in varying degrees of effectiveness ${ }^{\mathbf{4 3 , 5 0 - 5 2}}$. Guarro et al. tested nine Basidiobolus spp. and eight Conidiobolus spp. isolates for susceptibility. Basidiobolus spp. exhibits lower geometric 
mean MIC values than those for Conidiobolus spp.: itraconazole at $1.8 \mathrm{vs}$. $11.3 \mathrm{lg} \mathrm{mL}$, ketoconazole at 1.0 vs. $20.7 \mathrm{lg} \mathrm{mL}$, miconazole at 3.9 vs. 11.3 $\lg \mathrm{mL}$, and amphotericin $\mathrm{B}$ at 2.7 vs. $3.1 \mathrm{lg} \mathrm{mL}$. There is no clinical experience with voriconazole in the treatment of entomophthoromycosis. Over four years, the remarkable work of Krishnan et al. shows there to be a substantial improvement with potassium iodide at $40 \mathrm{mg} \mathrm{kg}$ per day in 9 of 10 patients with either basidiobolomycosis or conidiobolomycosis ${ }^{52}$. Amphotericin B has been linked to clinical failure ${ }^{53}$. Itraconazole or potassium iodide seem to be good first-line treatments ${ }^{49,53}$. There is no one antifungal drug with a consistent antifungal action. In-vitro susceptibility testing may aid in treatment planning ${ }^{49,52}$.

\section{CONCLUSION}

The relationship between diabetes, COVID-19, and the black fungus is that diabetes weakens the immune system. This helps to attack the COVID-19 virus. The decline of the immune system facilitates secondary infections such as that of the mucous fungus, especially in the recovery phase from the virus. Most cases of the black fungus are closely related to COVID-19. Most COVID-19 patients are confined due to intensive care with the assistance of oxygen devices. In this case, the humidity is high, paving the way for easy infection by the fungi. As a result, researchers and healthcare practitioners must quickly address mucormycosis infection by evaluating its impact and severity, particularly in COVID-19 victims. A multidisciplinary method can be performed including a timely diagnosis, antifungal therapy, and suitable surgical consultation or treatments. More evaluation of the impact of mucormycosis in COVID-19 ongoing and recovered patients is needed. Recovering patients should be recommended to stay in quarantine for some weeks. This is where the immunity can be improved through the use of follow-up tests to rule out any complications. Comparable precautions must be undertaken for people infected with the virus. Hand washing, masking, and social distancing should be followed by normal public health routines.

\section{ABBREVIATIONS}

None.

\section{ACKNOWLEDGMENTS}

None.

\section{AUTHOR'S CONTRIBUTIONS}

All authors have sufficiently contributed to the manuscript. All authors read and approved the final manuscript.

\section{FUNDING}

None.

\section{AVAILABILITY OF DATA AND MATERIALS}

Not applicable.

\section{ETHICS APPROVAL AND CONSENT TO PARTICIPATE}

Not applicable.

\section{CONSENT FOR PUBLICATION}

Not applicable.

\section{COMPETING INTERESTS}

The authors declare that they have no competing interests.

\section{REFERENCES}

1. Petrikkos G, Skiada A, Lortholary O, Roilides E, Walsh TJ, Kontoyiannis DP. Epidemiology and clinical manifestations of mucormycosis. Clinical Infectious Diseases. 2012;54(S1):S23-S34. Available from: 10.1093/cid/cir866.

2. Chouhan AS, Parihar B, Rathod B, Prajapat R. Overuse of Steroid Drugs Methylprednisolone and Dexamethasone (Oral) Causes a Diabetic Patient to Become Infected With the Black Fungus of the Corona Virus. researchsquarecom. 2021;p. Preprint. Available from: 10.21203/rs.3.rs-747403/v1.

3. Rocha CN, Goyal S, Patel T, Jain S, Ghosh A. COVID-19 and Mucormycosis Syndemic: Double Health Threat to a Collapsing Healthcare System in India. Tropical Medicine \& International Health. 2021;26(9):1016-1018. PMID: 34117677. Available from: $10.1111 / \mathrm{tmi} .13641$.

4. Abdelhafiz AS, Mohammed Z, Ibrahim ME, Ziady HH, Alorabi $M$, Ayyad M. Knowledge, perceptions, and attitude of Egyptians towards the novel coronavirus disease (COVID-19). Journal of Community Health. 2020;45(5):881-90. PMID: 32318986. Available from: 10.1007/s10900-020-00827-7.

5. Hassany M, Abdel-Razek W, Asem N, AbdAllah M, Zaid H. Estimation of COVID-19 burden in Egypt. The Lancet Infectious Diseases. 2020;20(8):896-7. PMID: 32353346. Available from: 10.1016/S1473-3099(20)30319-4.

6. Dyer O. Covid-19: India sees record deaths as 'black fungus' spreads fear. BMJ. 2021;373:n1238. PMID: 33985993. Available from: 10.1136/bmj.n1238.

7. Mohammad SA, Osman AM, Abd-Elhameed AM, et al. The battle against Covid-19: the experience of an Egyptian radiology department in a university setting. The Egyptian Journal of Radiology and Nuclear Medicine. 2020;51:216. PMID: PMC7592454. Available from: 10.1186/s43055-020-00335-7.

8. Mahalaxmi I, Jayaramayya K, Venkatesan D, Subramaniam MD, Renu K, Vijayakumar P. Mucormycosis: an opportunistic pathogen during COVID-19. Environmental Research. 2021;201:111643. PMID: 34237335. Available from: 10.1016/j. envres.2021.111643.

9. Selvamurugan S. Current Scenario and the way to protect us from Black Fungus: A review. Journal of Pharmaceutical Advanced Research. 2021;4(6):1302-1306. 
10. Al-Tawfiq JA, Alhumaid S, Alshukairi AN, Temsah MH, Barry M, Mutair AA. COVID-19 and mucormycosis superinfection: the perfect storm. Infection. 2021;49(5):833-53. PMID: 34302291. Available from: 10.1007/s15010-021-01670-1.

11. Asrani P, Eapen MS, Hassan MI, Sohal SS. Implications of the second wave of COVID-19 in India. The Lancet Respiratory Medicine. 2021;9(9):e93-4. PMID: 34216547. Available from: 10.1016/S2213-2600(21)00312-X.

12. World Health Organization. Coronavirus disease (COVID-19). 2020. Situation Report. 2020;116.

13. Ezeokoli OT, Gcilitshana O, Pohl CH. Risk Factors for Fungal Co-Infections in Critically III COVID-19 Patients, with a Focus on Immunosuppressants. Journal of Fungi (Basel, Switzerland). 2021;7(7):545. PMID: 34356924. Available from: 10 3390/jof7070545

14. Ezeokoli OT, Pohl CH. Opportunistic pathogenic fungal coinfections are prevalent in critically ill COVID-19 patients: are they risk factors for disease severity? South African Medical Journal. 2020;110(11):1081-5. PMID: 33403982. Available from: 10.7196/SAMJ.2020.v110i11.15248.

15. Song $\mathrm{G}$, Liang $\mathrm{G}$, Liu W. Fungal co-infections associated with global COVID-19 pandemic: a clinical and diagnostic perspective from China. Mycopathologia. 2020;185(4):599-606. PMID: 32737747. Available from: 10.1007/s11046-020-00462-9.

16. Salmanton-García J, Sprute R, Stemler J, Bartoletti M, Dupont $\mathrm{D}$, Valerio $\mathrm{M}$, et al. COVID-19 associated pulmonary aspergillosis, March August 2020. Emerging Infectious Diseases. 2021;27(4):1077-86. PMID: 33539721. Available from: 10.3201/eid2704.204895.

17. Bartoletti $M$, Pascale $R$, Cricca $M$, Rinaldi $M$, Maccaro $A$, Bussini $L$, et al. Epidemiology of invasive pulmonary aspergillosis among COVID-19 intubated patients: a prospective study. Clinical Infectious Diseases. 2020;2020:ciaa1065. PMID: 32719848. Available from: 10.1093/cid/ciaa1065.

18. Abuyassin B, Laher I. Diabetes epidemic sweeping the Arab world. World Journal of Diabetes. 2016;7(8):165-74. PMID: 27114755. Available from: $10.4239 /$ wjd.v7.i8.165

19. Gambhir RS, Aggarwal A, Bhardwaj A, Kaur A, Sohi RK, Mehta S. Covid-19 and mucormycosis (Black Fungus): an epidemic within the pandemic. Roczniki Panstwowego Zakladu Higieny. 2021;72(3):239-44. PMID: 34553877.

20. Rees JR, Pinner RW, Hajjeh RA, Brandt ME, Reingold AL. The epidemiological features of invasive mycotic infections in the San Francisco Bay area, 1992-1993: results of populationbased laboratory active surveillance. Clinical Infectious Diseases. 1998;27(5):1138-47. PMID: 9827260. Available from: 10.1093/clinids/27.5.1138.

21. Barwal TS, Sharma U, Bazala S, Singh I, Jain M, Prakash H. MicroRNAs and Long Noncoding RNAs as Novel Therapeutic Targets in Estrogen Receptor-Positive Breast and Ovarian Cancers. International Journal of Molecular Sciences. 2021;22(8):4072. PMID: 33920789. Available from: 10.3390/ ijms 22084072 .

22. Elbossaty WF. The Black Fungus is One of the Bad Consequences of COVID 19. Clinics of Oncology. 2021;5(2):1-4.

23. Bonifaz A, Tirado-Sánchez A, Hernández-Medel ML, Araiza J, Kassack JJ, Angel-Arenas TD. Mucormycosis at a tertiary-care center in Mexico. A 35-year retrospective study of 214 cases. Mycoses. 2021;64(4):372-80. PMID: 33253454. Available from: $10.1111 /$ myc.13222.

24. Santosh AB, Muddana K, Bakki SR. Fungal infections of oral cavity: diagnosis, management, and association with COVID19. SN Comprehensive Clinical Medicine. 2021;3(11):1-2. PMID: 34541457. Available from: 10.1007/s42399-021-010339.

25. Kim JS, Lee JY, Yang JW, Lee KH, Effenberger M, Szpirt W. Immunopathogenesis and treatment of cytokine storm in COVID-19. Theranostics. 2021;11(1):316-29. PMID: 33391477. Available from: 10.7150/thno.49713.

26. Hoskin P, Ostler P. Clinical oncology: basic principles and practice. CRC Press; 2020. Available from: 10.1201/ 9781315267081
27. de Regt MJ, Murk JL, Schneider-Hohendorf T, Wattjes MP, Hoepelman Al, Arends JE. Progressive multifocal leukoencephalopathy and black fungus in a patient with rheumatoid arthritis without severe lymphocytopenia. JMM Case Reports. 2016;3(4):e005053. PMID: 28348775. Available from: 10.1099/jmmcr.0.005053.

28. Raza AF, Paudel DR, Prabhu P. Black fungus and COVID19: role of otorhinolaryngologists and audiologists. European Archives of Oto-Rhino-Laryngology. 2021;278(8):31334. PMID: 34121132 . Available from: 10.1007/s00405-02106932-0.

29. Moore G, Rickard H, Stevenson D, Aranega-Bou P, Pitman J, Crook A. Detection of SARS-CoV-2 within the healthcare environment: a multi-centre study conducted during the first wave of the COVID-19 outbreak in England. The Journal of Hospital Infection. 2021;108:189-96. PMID: 33259882. Available from: 10.1016/j.jhin.2020.11.024.

30. Gandra S, Ram S, Levitz SM. The 'Black Fungus' in India: The Emerging Syndemic of COVID-19 Associated Mucormycosis. American College of Physicians; 2021.

31. Chowdhary A, Agarwal K, Meis JF. Filamentous fungi in respiratory infections. What lies beyond Aspergillosis and $\mathrm{Mu}$ cormycosis? PLoS Pathogens. 2016;12(4):e1005491. PMID: 27124489. Available from: 10.1371/journal.ppat.1005491.

32. Singh AK, Singh R, Joshi SR, Misra A. Mucormycosis in COVID-19: A systematic review of cases reported worldwide and in India. Diabetes \{\&amp; $\} a m p ;$ Metabolic Syndrome. 2021;15(4):102146. PMID: 34192610. Available from: 10.1016/ j.dsx.2021.05.019.

33. Hegazi R, El-Gamal M, Abdel-Hady N, Hamdy O. Epidemiology of and risk factors for type 2 diabetes in Egypt. Annals of Global Health. 2015;81(6):814-20. PMID: 27108148. Available from: 10.1016/j.aogh.2015.12.011.

34. Bhogireddy R, Krishnamurthy V, Pullaiah CP, Manohar S. Is Mucormycosis an inevitable complication of Covid-19 in India? Braz J Infect Dis. 2021;25(3):101597. PMID: 34289382. Available from: 10.1016/j.bjid.2021.101597.

35. Corzo-León DE, Chora-Hernández LD, Rodríguez-Zulueta AP, Walsh TJ. Diabetes mellitus as the major risk factor for mucormycosis in Mexico: Epidemiology, diagnosis, and outcomes of reported cases. Medical Mycology. 2018;56(1):2943. PMID: 28431008. Available from: $10.1093 / \mathrm{mmy} / \mathrm{myx} 017$.

36. Thabet AA, Mahran HG, Ebid AA, Alshehri MA. Effect of pulsed high intensity laser therapy on delayed caesarean section healing in diabetic women. Journal of Physical Therapy Science. 2018;30(4):570-5. PMID: 29706708. Available from: 10.1589/jpts.30.570.

37. Elkhalifa AE, Al-Shammari E, Adnan M, Alcantara JC, Mehmood K, Eltoum NE. Development and Characterization of Novel Biopolymer Derived from Abelmoschus esculentus L. Extract and Its Antidiabetic Potential. Molecules (Basel, Switzerland). 2021;26(12):3609. PMID: 34204669. Available from: 10.3390/ molecules 26123609 .

38. Allaq AA, Sidik NJ, Abdul-Aziz A, Alkamil AM, Elengoe A, Yahya $E B$, et al. Epidemiological studies of the novel coronavirus (covid-19) in Libya. Pakistan Journal of Biotechnology. 2021;18(1):7-16.

39. Gupta G, S R, Singh Y, Thangavelu L, Singh SK, Dureja H. Emerging cases of mucormycosis under COVID-19 pandemic in India: misuse of antibiotics. Drug Development Research. 2021;82(7):880-2. PMID: 34323298. Available from: 10.1002/ ddr. 21862 .

40. Singh AK, Singh R, Joshi SR, Misra A. Mucormycosis in COVID19: A systematic review of cases reported worldwide and in India. Diabetes \& Metabolic Syndrome. 2021;15(4):102146. PMID: 34192610. Available from: 10.1016/j.dsx.2021.05.019.

41. Mohamed A, Hassan T, Trzos-Grzybowska M, Thomas J, Quinn A, O'Sullivan M. Multi-triazole-resistant Aspergillus fumigatus and SARS-CoV-2 co-infection: A lethal combination. Medical Mycology Case Reports. 2021;31:11-4. PMID: 32837879. Available from: 10.1016/j.mmcr.2020.06.005. 
42. Woods JA, Hutchinson NT, Powers SK, Roberts WO, GomezCabrera MC, Radak Z. The COVID-19 pandemic and physical activity. Sports Med Health Sci. 2020;2(2):55-64. PMID: 34189484. Available from: 10.1016/j.smhs.2020.05.006.

43. Bhadra A, Ahmed MS, Rahman MA, Islam S. Mucormycosis or black fungus: An emerging threat in COVID-19. Bangabandhu Sheikh Mujib Medical University Journal. 2021;14(3):51-56. Available from: 10.3329/bsmmuj.v14i3.54682.

44. Burdová P. Monitoring přenosu mykotického infekčního agens z domácího zviřete na člověka. Univerzita Hradec Králové; 2014.

45. Qader M, Zaman KH, Hu Z, Wang C, Wu X, Cao S. Aspochalasin H1: A New Cyclic Aspochalasin from Hawaiian Plant-Associated Endophytic Fungus Aspergillus sp. FT1307. Molecules (Basel, Switzerland). 2021;26(14):4239. PMID: 34299514. Available from: 10.3390/molecules26144239.

46. Sharma A, Verma SK, Sharma MS, Yadav OP. Black Fungus "Pandemic With In the Pandemic". International Journal of All Research Education and Scientific Methods. 2021;9(5):23832384.

47. Skiada A, Lass-Floerl C, Klimko N, Ibrahim A, Roilides E, Petrikkos G. Pulmonary Mucormycosis: A Case Report of a Rare Infection with Potential Diagnostic Problems. Case Reports in Pathology. 2020;2020:5845394. Available from: $10.1155 / 2020 / 5845394$.

48. Skiada A, Pavleas I, Drogari-Apiranthitou M. Epidemiology and diagnosis of mucormycosis: an update. Journal of Fungi
(Basel, Switzerland). 2020;6(4):265. PMID: 33147877. Available from: 10.3390/jof6040265.

49. Shinde YB, Kore S. A Review on Mucormycosis with recent pharmacological treatment. Journal of Drug Delivery and Therapeutics. 2021;11(3-S):145-9. Available from: 10.22270/ jddt.v11i3-S.4844.

50. Rawlani SS, Siddiqui A, Reza M, Chelkar S, Rani T, Roy HKB. Black Fungus Mucormycosis, Epidemiology, Etiopathogenesis, Clinical Diagnosis, Histopathology and its Management-A Review. Int J Med Dent Res. 2021;1(2):1-8. Available from: https://ijmadr.com/assets/ uploads/1621249725-Black\%20Fungus\%20Mucormycosis, \%20Epidemiology,\%20Etiopathogenesis, \%20Clinical\% 20Diagnosis, \%20Investigations, \%20Histopathology\%20and\% 20its\%20Management-\%20A\%20Review.pdf.

51. Steinbrink JM, Miceli MH. Mucormycosis. Infectious Disease Clinics of North America. 2021;35(2):435-52. PMID: 34016285. Available from: 10.1016/j.idc.2021.03.009.

52. Prabhu RM, Patel R. Mucormycosis and entomophthoramycosis: a review of the clinical manifestations, diagnosis and treatment. Clinical Microbiology and Infection. 2004;10:3147. PMID: 14748801. Available from: 10.1111/j.1470-9465. 2004.00843.x.

53. Holmes TR, Hepschke JL, Jacobson I, Maloof A. Mucormycosis: early treatment is the key to survival. The Medical Journal of Australia. 2021;215(9):401-3. PMID: 34628643. Available from: 10.5694/mja2.51290. 
Ready to submit your manuscript? Choose Biomedpress and benefit from:

- Fast, convenient online submission

- Through peer-review by experienced researchers

- Rapid publication on acceptance

- Free of charge (without publication fees)

Learn more http://www.biomedpress.org/journals/
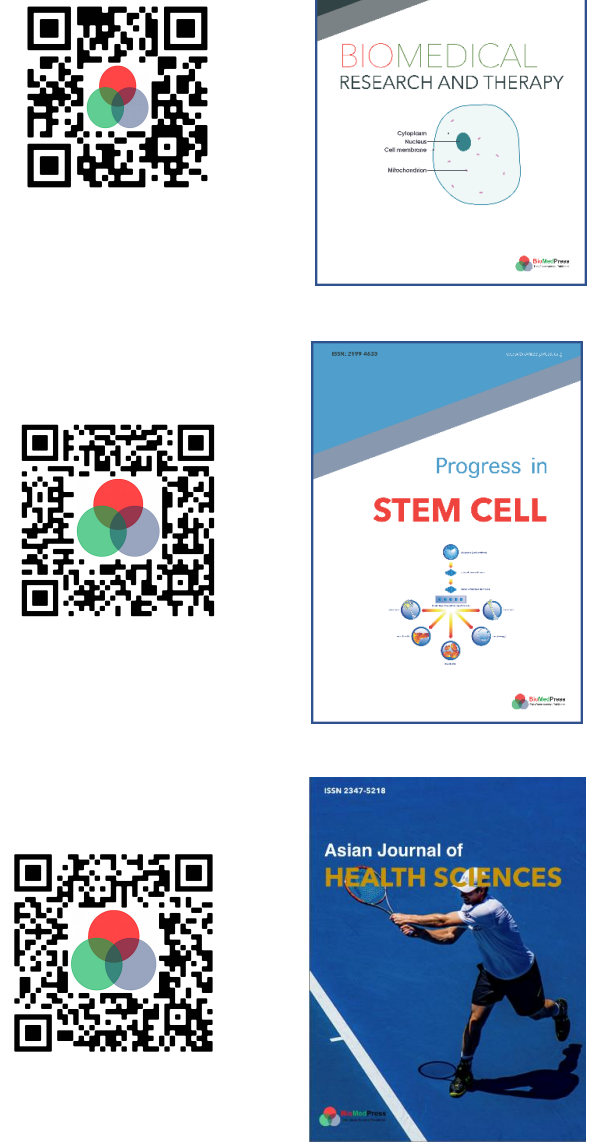

Asian Journal of Health Sciences

ISSN: 2347-5218

Indexed: Google Scholar

Acceptance Rate (2020): 72.89\%

Article Publishing Charge: Free

Submission to first editorial decision: 16.5 days

Biotechnological Research

ISSN: 2395-6763

Indexed: Google Scholar

Acceptance Rate (2020): $67.02 \%$

Article Publishing Charge: Free

Submission to first editorial decision: 28.5 days 